\title{
Wsparcie dzieci współczesnych polskich repatriantów $w$ adaptacji szkolnej
}

Streszczenie: Celem artykułu jest ukazanie wsparcia w sytuacji zmiany społecznej na przykładzie wsparcia dzieci repatriantów w adaptacji szkolnej. Przedstawiono w nim wyniki badań ankietowych i wywiadów pogłębionych przeprowadzonych wśród dzieci repatriantów, ich nauczycieli i rodziców. W interpretacji wyników badań wykorzystano koncepcję wsparcia społecznego Stanisława Kawuli. W opinii badanych bardzo pozytywny wpływ na adaptację szkolną dzieci repatriantów mają dodatkowe zajęcia organizowane na początku nauki w polskiej szkole. Niestety, niewielka świadomość nauczycieli na temat pracy z uczniem odmiennym kulturowo i nauczania języka polskiego jako obcego znacznie ogranicza efektywność tych zajęć. Niewystarczające jest też wsparcie informacyjne. Choć szkoła jako instytucja wprowadzająca kolejne pokolenia w świat kultury powinna reagować na zachodzące zmiany społeczne, przeprowadzone badania wskazują na niedostateczne przygotowanie nauczycieli do pracy z uczniem z doświadczeniem migracyjnym. Jest to efekt zaniedbań zarówno na etapie kształcenia wyższego, doskonalenia zawodowego, jak i informowania nauczycieli o sytuacji ucznia trafiającego do danej placówki. W środowiskach szkolnych objętych badaniami nauczyciele wykazywali się ogromnym zaangażowaniem we wsparcie dzieci repatriantów w adaptacji szkolnej, lecz ich dobra wola była niewystarczająca, aby kompensować brak profesjonalizmu działań, sprawnej komunikacji czy nawet znajomości prawa oświatowego.

Słowa kluczowe: repatriacja, adaptacja szkolna, dzieci z doświadczeniem migracyjnym

Wsparcie i wspomaganie drugiego człowieka jest łączone jednoznacznie z poczuciem wspólnotowości życia w konkretnym kręgu środowiskowym i zakorzenienia w danym miejscu (Kawula, 2012, s. 153). Coraz więcej ludzi z powodu różnorodnych migracji nie ma poczucia zakorzeniania w swoim miejscu zamieszkania lub nie identyfikuje się z żadną małą ojczyzną.

Jednym z typów migracji obserwowanych od 1992 roku jest współczesna polska repatriacja, czyli osiedlanie się na terenie Polski osób polskiej narodowości, które przed 2001 rokiem mieszkały na stałe w azjatyckiej części daw- 
nego Związku Radzieckiego (Ustawa z dnia 9 listopada 2000 r. o repatriacji, art. 5 pkt 1). Współcześni repatrianci to przede wszystkim potomkowie Polaków deportowanych w latach trzydziestych XX wieku w głąb ZSRR z terenów dzisiejszej Ukrainy i Białorusi, a od 2017 roku również ich małżonkowie

$\mathrm{Na}$ temat współczesnej polskiej repatriacji powstały prace z zakresu politologii (Hut, 2014), socjologii (Sałacińska-Rewiakin, 2014), psychologii (Gorbaniuk, 2008), pedagogiki (Jakubowska, 2011), a także opracowania interdyscyplinarne (Kość-Ryżko, 2014; Świdrowska, 2016), lecz kwestie związane z dziećmi współczesnych repatriantów stanowią margines poczynań badawczych (Książek, 2019, s. 212) lub są zupełnie pomijane.

Celem tego artykułu jest ukazanie wsparcia w sytuacji zmiany społecznej na przykładzie wsparcia dzieci repatriantów w adaptacji szkolnej. Temat ten stanowi część szerszej problematyki, jaką jest obecności dzieci z doświadczeniem migracyjnym w polskich szkołach.

Migracje są jedną z najbardziej znaczących zmian społecznych w naszym kraju. Zmiana społeczna to „zespół nieuchronnych procesów, dzięki którym społeczeństwo przechodzi na kolejny szczebel rozwoju. Istniejące i obowiązujące formy życia przeżywają się, rodzą się nowe, lepiej odpowiadające zmieniającym się warunkom, potrzebom, oczekiwaniom" (Radziewicz-Winnicki, 2004, s. 30). Powstają wobec tego pytania: Jakie formy wsparcia odpowiadają warunkom, potrzebom i oczekiwaniom społeczeństw, dla których migracje nieuchronnie stają się codziennością? Jakie wsparcie otrzymują migranci w nowym środowisku od osób zakorzenionych w danym miejscu?

\section{Założenia metodologiczne badań własnych}

Badania miały na celu poznanie sposobów wsparcia społecznego dzieci repatriantów w adaptacji szkolnej poprzez próbę odpowiedzi na pytanie, w jaki sposób były lub są one wspierane w tym obszarze adaptacji przez nauczycieli, rodziców oraz instytucje pozaszkolne. Badania przeprowadzono w latach 2014-2016 w województwach: dolnośląskim, opolskim i śląskim. W badaniach ankietowych zastosowano dobór oparty na dostępności badanych. Do 18 szkół w 11 miejscowościach przekazano 120 kwestionariuszy ankiet. Analizie poddano 73 kwestionariusze wypełnione przez 43 nauczycieli, 12 dzieci repatrian-

1 Nowelizacja ustawy o repatriacji pozwala uzyskać status repatrianta i wiążące się z nim przywileje małżonkom repatriantów, ich zstępnym do czwartego stopnia oraz małżonkom tychże zstępnych (Ustawa z dnia 7 kwietnia 2017 roku o zmianie ustawy o repatriacji oraz niektórych innych ustaw, art. 1 pkt 5). 
tów i ich 18 rodziców. W badaniach jakościowych zastosowano dobór celowy. Osoby, z którymi przeprowadzono wywiady pogłębione, to:

- wicedyrektorka i pedagog szkolny, miejscowość I (wywiad 1-n-D),

- matka, miejscowość I (wywiad 2-r-D),

- matka, miejscowość II (wywiad 3-r-S),

- dyrektorka, miejscowość III (wywiad 4-n-S),

- matka, miejscowość III (wywiad 5-r-S),

- Rustem, 8 lat, miejscowość III (wywiad 6-u-S),

- nauczycielka historii i języka polskiego, miejscowość IV (wywiad 7 $\mathrm{n}-\mathrm{O})$,

- Pawlo, 8 lat, miejscowość IV (wywiad 8-u-O),

- dyrektor, miejscowość IV (wywiad 9-n-O),

- nauczycielka matematyki, miejscowość V (wywiad 10-n-O),

- matka, miejscowość VI (wywiad 11-r-S),

- wicedyrektorka, miejscowość VII (wywiad 12-n-D),

- nauczycielka wychowania fizycznego, miejscowość VII (wywiad 13-n-D).

Zgromadzony materiał empiryczny pomogła uporządkować typologia wsparcia społecznego zaproponowana przez Stanisława Kawulę (2012, s. 155-156). Przykłady wymienione przez badanych przyporządkowano czterem typom wsparcia społecznego: instrumentalnemu, informacyjnemu, wartościującemu i emocjonalnemu.

\section{Wsparcie instrumentalne: dodatkowe zajęcia lekcyjne}

W polskich szkołach dla uczniów z doświadczeniem migracyjnym można zorganizować bezpłatną naukę języka polskiego i zajęcia wyrównawcze z wybranych przedmiotów, o czym szczegółowo traktują rozporządzenia MEN.

Kiedy w 2014 roku rozpoczynano badania, dyrektorzy niektórych szkół nie wiedzieli, że istnieje taka forma wsparcia, czego przykładem jest rozmowa telefoniczna z dyrektorką szkoły, która na pytanie, czy dziecko z rodziny repatrianckiej z Kazachstanu uczy się w jej szkole, odpowiedziała: „Proszę pani! Ależ my nie możemy, my nawet nie mamy prawa pytać, skąd pochodzi uczeń! To by naruszało prywatność rodziny! Nam nie wolno posiadać takich informacji”. Kiedy zadano następne pytanie: „To na jakiej podstawie stwierdzają państwo, czy uczeń ma prawo do dodatkowych zajęć?”, po chwili ciszy padło zdanie kończące rozmowę: „Nie mamy takich dzieci”.

Odpowiadając na pytanie alternatywne półotwarte o to, czy uczeń z rodziny repatrianckiej otrzymywał lub otrzymuje wsparcie w adaptacji szkolnej ze 
strony nauczycieli, uczniów, rodziców kolegów i koleżanek, 33\% nauczycieli, 17\% uczniów i 17\% rodziców wymieniło dodatkowe zajęcia lekcyjne.

Na podstawie analizy wywiadów ustalono, że dla Franka² z miejscowości I, Rustema z miejscowości III i Soni z miejscowości VII zorganizowano w szkole nauczanie języka polskiego, natomiast Pawlo z miejscowości IV uczył się dodatkowo również angielskiego, specjalistycznych terminów z matematyki i słownictwa potrzebnego do rozwiązywania zadań tekstowych.

Respondenci z miejscowości I, III, IV i VII uważali, że dodatkowe zajęcia miały bardzo pozytywny wpływ na adaptację szkolną dzieci repatriantów, jednak dość znamienny wydaje się fakt, iż w żadnej z tych szkół nauczyciele nie posiadali kwalifikacji do nauczania języka polskiego jako obcego ani nawet nie poszukiwali informacji na temat metod, podręczników i innych przydatnych do tego pomocy. Niewiedza nauczycieli na ten temat skutkowała mniejszą efektywnością dodatkowych zajęć, co można nazwać brakiem spójności „między potrzebami biorcy a rodzajem udzielanego wsparcia" (Kawula, 2012, s. 154).

\section{Wsparcie instrumentalne: pomoc materialna}

Pomoc materialna nie należy do zadań szkoły, jednak ankietowani nauczyciele dwa razy wspomnieli o takiej formie wsparcia. W jednym przypadku szkoła zakupiła podręczniki dla ucznia z rodziny repatrianckiej, w drugim udzieliła wsparcia finansowego.

Jedna z ankietowanych matek przyznała, że od rodziców innych uczniów otrzymała pomoc finansową, lecz dowiedziała się o tym dopiero po dłuższym upływie czasu, a spiritus movens tak dyskretnie świadczonej pomocy była prawdopodobnie wychowawczyni klasy.

W miejscowości I wsparcie oferowane przez szkołę nie zostało przyjęte, o czym opowiadała badana wicedyrektorka: „Zaprosiłam panią Nowicką na rozmowę, bo jako pedagog chciałam zaoferować jakąś pomoc. Może mniej finansową, bo szkoła nie ma takiej możliwości, ale rzeczową. Prowadzimy taką pomoc rzeczową dla dzieci w formie kurtek, jakiegoś obuwia, zimowej odzieży. Staramy się pozyskać taką odzież (...) i rodziny potrzebujące bardzo chętnie korzystają z tego. Więc zapytałam panią Nowicką, czy potrzebuje takiego wsparcia, czy na przykład jakiegoś zwolnienia z opłat, z ubezpieczenia, ale była niechętna. Powiedziała, że oni są rodziną przedsiębiorczą, dała do zrozumienia, że jej mąż zawsze gdzieś tam pieniądze dorobi. Podziękowała za pomoc, po

2 Wszystkie imiona i nazwiska zostały zmienione na fikcyjne. 
prostu. Oni nigdy tutaj nie chcieli korzystać z takiej widocznej pomocy (chociaż ta jest bardzo dyskretna), natomiast z tej pomocy instytucjonalnej, która im się należy, to rzeczywiście korzystali i zawsze ta pomoc była świadczona na ich rzecz" (wywiad 1-n-D).

Odmowa pani Nowickiej nie kończy jednak tej historii. Jej syn Franek od drugiego roku w polskiej szkole otrzymywał co miesiąc 50 zł stypendium za wyniki w nauce. Badana pedagog podkreślała w wywiadzie jego uzdolnienia i pracowitość, lecz powiedziała również: „Zaangażowaliśmy, promowaliśmy go bardzo" (wywiad 1-n-D), zwracając w ten sposób uwagę na pracę dydaktyczną i wsparcie emocjonalne ze strony nauczycieli, które ułatwiły Frankowi rozwój i odnoszenie sukcesów.

Wśród instytucji pozaszkolnych wspierających adaptację szkolną dzieci repatriantów najczęściej były wskazywane ośrodki pomocy społecznej. Ich rolę dostrzegło $12 \%$ nauczycieli, $17 \%$ uczniów i $22 \%$ ankietowanych rodziców. To niewiele, biorąc pod uwagę, że OPS wypłaca zasiłek szkolny. Być może obligatoryjny charakter tej formy wsparcia czyni ją niedostrzegalną.

Wsparcie procesu adaptacji szkolnej przez urzędy miast i gmin uwzględniło w kwestionariuszach 7\% nauczycieli, 8\% uczniów i 1\% rodziców. W większości przypadków polegało ono na sfinansowaniu dodatkowych zajęć. Jedna ankietowana nauczycielka podała, że urząd miasta wyznaczył opiekunów rodziny. Było to rozwiązanie innowacyjne, ponieważ dopiero nowelizacja ustawy o repatriacji z 2017 roku uregulowała status osoby wspierającej repatrianta.

Pozostałe instytucje wymienione przez ankietowanych to: powiatowe centrum pomocy rodzinie (pośredniczy w wypłacaniu zasiłków dla repatriantów ze starostwa), centrum kształcenia ustawicznego (może prowadzić kursy adaptacyjne i językowe dla repatriantów i ich rodzin) i ośrodek dla repatriantów w Nałęczowie. Ostatnia instytucja według ankietowanej nauczycielki zapewnia repatriantom: „naukę języka polskiego, pomoc w wypełnianiu dokumentów, wspólne spędzanie wolnego czasu". Respondentka zapewne miała na myśli nałęczowskie Centrum Szkoleniowo-Wypoczynkowe „Energetyk”, gdzie Fundacja „Ocalenie” kilkakrotnie prowadziła kursy adaptacyjne na zlecenie ORPEG.

\section{Wsparcie informacyjne: przygotowanie nauczycieli do pracy z dziećmi repatriantów}

Większość polskiego społeczeństwa niewiele wie na temat współczesnej polskiej repatriacji, a w programach kształcenia pedagogicznego od niedawna pojawia się przygotowanie do pracy z uczniem odmiennym kulturowo. Dla- 
tego wsparcie informacyjne dla nauczycieli przed przyjęciem ucznia z zagranicy wydaje się sprawą kluczową.

Z wywiadów przeprowadzonych z dyrektorem (wywiad 9-n-O) i wicedyrektorkami (wywiady 1-n-D, 12-n-D) wynika, że informacja o pojawieniu się w ich placówkach dzieci repatriantów docierała do nich bardzo późno i nie towarzyszyły jej żadne bliższe informacje ani o rodzinie, ani o wsparciu przysługującym nowym uczniom, ani też o możliwych problemach i sposobach ich unikania bądź rozwiązywania.

Ankietowani nauczyciele de facto nie otrzymywali żadnego wsparcia informacyjnego, lecz mimo to $91 \% \mathrm{z}$ nich stwierdziło, że grono pedagogiczne było przygotowane do pracy z dziećmi repatriantów. W tabeli 1 można zauważyć, że tylko $42 \%$ badanych dzieci repatriantów podzielało ich zdanie. Widać również, że więcej badanych dzieci uznało za bardziejprzygotowanych innych uczniów (58\%) niż nauczycieli (42\%), co może wynikać z różnicy w oczekiwaniach wobec tych dwóch grup. Przypuszczać można, że nauczycielom łatwiej jest przygotować innych uczniów w oparciu o intuicję, wiedzę ogólnopedagogiczną i potoczną, niż przygotować siebie (w pośpiechu i bez wsparcia informacyjnego) na nową sytuację, która wymaga specjalistycznej wiedzy.

Tabela 1. Przygotowanie nauczycieli i uczniów do kontaktu z dziećmi repatriantów

\begin{tabular}{|l|c|c|c|c|c|}
\hline \multirow{2}{*}{ Grupa badana } & \multicolumn{5}{|c|}{ Przygotowanie do kontaktu z dzieckiem repatrianta } \\
\cline { 2 - 6 } & \multicolumn{2}{|c|}{ nauczycieli } & \multicolumn{3}{c|}{ innych uczniów } \\
\cline { 2 - 6 } & TAK [\%] & NIE[\%] & TAK [\%] & NIE[\%] & NIE WIEM[\%] \\
\hline Nauczyciele $n=43$ & 91 & 9 & 70 & 5 & 25 \\
\hline Uczniowie $n=12$ & 42 & 58 & 58 & 17 & 25 \\
\hline Rodzice $n=18$ & 83 & 17 & 44 & 11 & 45 \\
\hline
\end{tabular}

Źródło: badania własne.

Nauczycieli zapytano o to samo w dalszej części kwestionariusza w pytaniu alternatywnym półotwartym i tam już tylko $83 \%$ uznało grono pedagogiczne w swojej szkole za przygotowane do pracy z dziećmi repatriantów, przy czym dla $76 \%$ ogółu badanych z tej grupy przygotowaniem była informacja przekazana przez dyrektora. Co czwarty badany nauczyciel za przygotowanie uznał wcześniejsze doświadczenia własne lub swoich znajomych, a 4\% przygotowało się dzięki informacjom z mediów, głównie z Internetu.

Uczniowie, zapytani o sposób przygotowania nauczycieli, zwrócili uwagę na znajomość niektórych słów w języku rosyjskim, umiejętność wyjaśniania trudniejszych zagadnień w czasie lekcji i tłumaczenie zasad kultury polskiej. 
Rodzice $\mathrm{w}$ większości dobrze ocenili przygotowanie nauczycieli do pracy z ich dziećmi, lecz odpowiadając na pytanie o sposób tego przygotowania, koncentrowali się wyłącznie na informacjach przekazanych przez dyrekcję lub urząd gminy.

Warto zwrócić uwagę na fakt, że w badanych szkołach uczniowie tylko przez przypadek trafiali do klas prowadzonych przez nauczycieli władających językiem rosyjskim. Jedna z ankietowanych nauczycielek napisała, że gdyby wcześniej dowiedziała się o przybyciu ucznia z rodziny repatrianckiej, przypomniałaby sobie język rosyjski, aby móc się z nim swobodniej komunikować w pierwszych tygodniach.

\section{Wsparcie wartościujące: dzielenie się wiedzą na temat swojego kraju pochodzenia}

Możliwość dzielenia się wiedzą na temat kraju pochodzenia daje dzieciom z doświadczeniem migracyjnym poczucie akceptacji w nowym środowisku i podstawę do kształtowania tożsamości dwukulturowej, a innym uczniom pomaga w rozwoju poznawczym, jak również pozwala kształtować otwartość i kompetencje międzykulturowe.

Ankietowanych pedagogów poproszono o ustosunkowanie się na pięciostopniowej skali Likerta do zdania: Uczeń z rodziny repatrianckiej chętnie dzieli się z innymi kultura kraju, z którego przybyt (np. znajomościa geografii, historii, zwyczajów, języka rosyjskiego). Wyniki przedstawione w tabeli 2 pokazują, że aż 67\% badanych uczniów bardzo chętnie dzieli się kulturą kraju pochodzenia, tymczasem zaledwie $33 \%$ nauczycieli to dostrzega.

Tabela 2. Stosunek do stwierdzenia: „Uczeń z rodziny repatrianckiej chętnie dzieli się z innymi kulturą kraju, z którego przybył (np. znajomością geografii, historii, zwyczajów, języka rosyjskiego)" lub analogicznego w grupie uczniów i rodziców

\begin{tabular}{|l|c|c|c|}
\hline \multicolumn{1}{|c|}{$\begin{array}{c}\text { Kategorie odpowiedzi } \\
\text { (skala Likerta) }\end{array}$} & $\begin{array}{c}\text { Nauczyciele } \\
n=43[\%]\end{array}$ & $\begin{array}{c}\text { Uczniowie } \\
n=12[\%]\end{array}$ & $\begin{array}{c}\text { Rodzice } \\
n=18[\%]\end{array}$ \\
\hline Całkowicie nie zgadzam się & 2 & 0 & 0 \\
\hline Raczej nie zgadzam się & 9 & 0 & 11 \\
\hline Nie mam zdania & 19 & 0 & 17 \\
\hline Raczej zgadzam się & 37 & 33 & 22 \\
\hline Całkowicie zgadzam się & 33 & 67 & 50 \\
\hline
\end{tabular}

Źródło: badania własne.

Badanych pedagogów poproszono dodatkowo o ustosunkowanie się do stwierdzenia: Nauczyciele stwarzaja okazje do dzielenia się wiedza i umiejęt- 
nościami zdobytymi w kraju, z którego przybyt uczeń z rodziny repatrianckiej. Całkowicie z tym zdaniem zgodziło się $42 \%$ badanych, raczej zgodziło się $33 \%$, nie miało zdania 16\%, raczej nie zgodziło się 9\%. Potwierdza to, że dzieci repatriantów znacznie chętniej dzielą się wiedzą, niż sądzą nauczyciele, lecz brakuje im ku temu okazji.

Przeprowadzone wywiady pogłębione dostarczyły dwóch przykładów dzielenia się wiedzą na temat swojego kraju pochodzenia przez dzieci repatriantów. W miejscowości I było to zasługą nauczycieli, którzy od początku umożliwiali Frankowi Nowickiemu udział w corocznych konkursach z języka rosyjskiego (wywiad nr 2-r-D). Kiedy kilka lat później jego młodszy brat Kazik rozpoczął naukę w tej samej szkole podstawowej, również doceniano jego znajomość języka rosyjskiego: „Pani w nauczaniu początkowym prowadziła na przykład takie zajęcia, że Kazik czytał dzieciom w języku rosyjskim na przykład bajkę »Czerwony Kapturek«. Najpierw była w języku polskim, a później w rosyjskim" (wywiad nr 1-n-D). Tamtejsza szkoła zorganizowała też spotkanie otwarte z babcią Franka i Kazika, podczas którego seniorka rodu opowiedziała o wielopokoleniowej wędrówce ich rodziny.

W miejscowości VII nauczyciele nie zabiegali o dzielenie się kulturą kazachską, którą znało troje dzieci repatriantów uczęszczających do tamtejszej placówki, lecz uczęszczająca do piątej klasy Helena wykorzystywała każdą okazję, aby opowiadać o Kazachstanie i losach swojej rodziny, o czym wspomniała w wywiadzie jej wychowawczyni: „Helena zna super historie rodzinne, po prostu rewelacja! Widać, że się tym interesuje. (...) Na przykład jak robiliśmy wigilię klasową, to Helenka przygotowała takie potrawy z Kazachstanu - jakąś kutię zrobiła, sałatkę taką z ryżu bodajże, już nie pamiętam. (...) Jak opowiadamy jakieś tradycje, to Helenka też opowiada: »A w Kazachstanie jest tak i tak«. (...) Najlepsze było, jak był mecz piłki nożnej Polska - Kazachstan. Wracaliśmy wtedy z obozu i pytam: »Helenka, komu będziesz kibicować? «, a Helenka tak patrzy i mówi: »Nie wiem« (śmiech)” (wywiad 13-n-D).

\section{Wsparcie emocjonalne: zaangażowanie rodziców w edukację szkolną dzieci}

Wsparcie emocjonalne polega na dawaniu komunikatów typu: „kochamy cię”, „masz mocne cechy charakteru”, „nie poddawaj się" (Kawula, 2012, s. 154). Jego podstawowym źródłem jest rodzina.

W miejscowości I rodzice Franka Nowickiego czuli się bezradni, gdy z powodu braku znajomości języka polskiego nie mogli pomóc synowi w nauce 
i odrabianiu zadań domowych (wywiad nr 2-r-D). Wsparcie emocjonalne nie ogranicza się jednak do znajomości języka, o czym świadczą słowa badanej pedagog: „Franek miał w domu bardzo duże wsparcie. Rodzice bardzo zabiegali o edukację, wspierali go naprawdę mocno" (wywiad 1-r-D).

Zaangażowanie rodziców z rodzin repatrianckich w edukację dzieci przejawia się również w ich kontakcie ze szkołą. W tabeli 3 można zauważyć, że większość (67\%) rodziców, połowa uczniów i tylko 40\% nauczycieli uznało, iż rodzice $\mathrm{z}$ rodzin repatrianckich pozostają w stałym kontakcie ze szkołą.

Tabela 3. Stosunek do stwierdzenia: „Rodzice ucznia z rodziny repatrianckiej pozostaja w stałym kontakcie ze szkołą" lub analogicznego w grupie uczniów i rodziców

\begin{tabular}{|l|c|c|c|}
\hline \multicolumn{1}{|c|}{$\begin{array}{c}\text { Kategorie odpowiedzi } \\
\text { (skala Likerta) }\end{array}$} & $\begin{array}{c}\text { Nauczyciele } \\
n=43[\%]\end{array}$ & $\begin{array}{c}\text { Uczniowie } \\
n=12[\%]\end{array}$ & $\begin{array}{c}\text { Rodzice } \\
n=18[\%]\end{array}$ \\
\hline Całkowicie nie zgadzam się & 2 & 0 & 0 \\
\hline Raczej nie zgadzam się & 8 & 0 & 0 \\
\hline Nie mam zdania & 23 & 8 & 11 \\
\hline Raczej zgadzam się & 27 & 42 & 22 \\
\hline Całkowicie zgadzam się & 40 & 50 & 67 \\
\hline
\end{tabular}

Źródło: badania własne.

Badanych poproszono również o ustosunkowanie się do stwierdzenia: Rodzice ucznia $z$ rodziny repatrianckiej angażuja się $w$ życie szkoty lub klasy bądź analogicznego w grupie uczniów i rodziców. W tabeli 4 można zauważyć, że większość nauczycieli nie wyraziła zdania na ten temat, natomiast uczniowie i rodzice najczęściej raczej zgadzali się z tym zdaniem.

Tabela 4. Stosunek do stwierdzenia: „Rodzice ucznia z rodziny repatrianckiej angażują się w życie szkoły lub klasy" lub analogicznego w grupie uczniów i rodziców

\begin{tabular}{|l|c|c|c|}
\hline $\begin{array}{c}\text { Kategorie odpowiedzi } \\
\text { (skala Likerta) }\end{array}$ & $\begin{array}{c}\text { Nauczyciele } \\
n=43[\%]\end{array}$ & $\begin{array}{c}\text { Uczniowie } \\
n=12[\%]\end{array}$ & $\begin{array}{c}\text { Rodzice } \\
n=18[\%]\end{array}$ \\
\hline Całkowicie nie zgadzam się & 8 & 0 & 0,00 \\
\hline Raczej nie zgadzam się & 5 & 0 & 11 \\
\hline Nie mam zdania & 55 & 33 & 22 \\
\hline Raczej zgadzam się & 21 & 59 & 45 \\
\hline Całkowicie zgadzam się & 13 & 8 & 22 \\
\hline
\end{tabular}

Źródło: badania własne.

Uzyskane wyniki badań ankietowych mogą świadczyć o tym, że rodzice starają się pozostawać w stałym kontakcie ze szkołą i czują się zaangażowani, natomiast nauczyciele - obserwując ich na tle innych rodziców - oceniają ich 
zaangażowanie słabiej lub powstrzymują się od oceny, gdy nie mają z nimi kontaktu. Analiza wywiadów nie wykazała, aby któryś z rodziców wykazywał się szczególnie wysoką aktywnością w tym zakresie.

\section{Podsumowanie}

Przeprowadzone badania ukazały duży potencjał wynikający z postawy nauczycieli wobec dzieci repatriantów. Za sprawą działań podejmowanych przez szkoły rodziny repatrianckie otrzymywały wsparcie wychodzące poza ramy określone prawem. Niestety, brak przygotowania do pracy z uczniem odmiennym kulturowo oraz brak wiedzy na temat dostępnych form wsparcia dla ucznia z doświadczeniem migracyjnym nie pozwalały w pełni wykorzystać ani pomocy systemowej, ani potencjału nauczycieli zaangażowanych we wsparcie dzieci repatriantów w adaptacji szkolnej.

\section{Bibliografia}

Gorbaniuk, J. 2008. Psychospołeczne uwarunkowania zadowolenia z repatriacji Polaków z Kazachstanu. Lublin: KUL.

Grzymała-Moszczyńska, H. i Grzymała-Kazłowska, A. 2011. Repatrianci $z$ Kazachstanu - charakterystyka i główne problemy adaptacyjne. Warszawa: Komitet Badań nad Migracjami.

Hut, P. 2014. Polska wobec Polaków w przestrzeni poradzieckiej. Od solidaryzmu etnicznego do obowiazku administracyjnego. Warszawa: Oficyna Wydawnicza ASPRA-JR

Jakubowska, L. 2011. Tożsamość kulturowa Polaków z Kazachstanu w kontekście tendencji globalizacyjnych. Legnica: PWSZ im. Witelona w Legnicy.

Kawula, S. 2012. Pedagogika społeczna dzisiaj i jutro. Toruń: Wydawnictwo Edukacyjne „Akapit”.

Kość-Ryżko, K. 2014. Wykorzenieni. Dylematy samookreślenia polskich repatriantów z Kazachstanu. Studium etno-psychologiczne. Warszawa: Instytut Archeologii i Etnologii PAN.

Książek, J. 2019. Adaptacyjne problemy dzieci repatriantów na tle relacji rówieśniczych. Migration Studies - Review of Polish Diaspora. 1 (171), ss. 211 -229 .

Radziewicz-Winnicki, A. 2004. Społeczeństwo w trakcie zmiany. Gdańsk: GWP. 
Sałacińska-Rewiakin, J. 2014. Deportowani i repatrianci. Trzy pokolenia kazachstańskich Polaków wobec problemu tożsamości. Warszawa: Narodowe Centrum Kultury.

Świdrowska, E. 2016. Repatriacja do polskich gmin - realia $i$ wyzwania. Raport z badań. Kraków: Instytut Wschodnich Inicjatyw.

Ustawa z dnia 7 kwietnia 2017 roku o zmianie ustawy o repatriacji oraz niektórych innych ustaw (Dz.U. 2017, poz. 858).

Ustawa z dnia 9 listopada 2000 roku o repatriacji (Dz.U. 2000, nr 106, poz. 1118 z późn. zm.).

\section{Support in school adaptation for the children of contemporary Polish repatriates}

Abstract: The aim of the article is to show support in the situation of social change on the example of supporting children of repatriates in school adaptation. It presents the results of surveys and in-depth interviews conducted among the children of repatriates, their teachers and parents. For interpreting the research results, Stanisław Kawula's concept of social support is used. In the opinion of the respondents, additional classes organized at the beginning of education at the Polish school have a very positive effect on the school adaptation of repatriates children. Unfortunately, the low awareness of teachers about working with a culturally different student and teaching Polish as a foreign language significantly reduces the effectiveness of these activities. Information support is also insufficient. Although the school as an institution introducing subsequent generations to the world of culture should react to the ongoing social changes, the conducted research indicates insufficient preparation of teachers to work with students with migration experience. This is the result of negligence both at the stage of higher education and professional development, as well as informing teachers about the situation of the student who reaches the given institution. In the school environments covered by the research, the teachers showed a great commitment to support the children of repatriates in school adaptation, but their good will was insufficient to compensate for the lack of professionalism, efficient communication or even knowledge of educational law.

Keywords: repatriation, school adaptation, children with migration experience 